\title{
ANALISIS TINDAK TUTUR DALAM DIALOG AHOK DENGAN MASYARAKAT DI PULAU SERIBU
}

\author{
Annisa Tri Sari \\ 8156191002 \\ Pendidikan Bahasa dan Sastra Indonesia
}

\begin{abstract}
Abstrak
Penelitian ini bertujuan untuk mendeskripsikan tindak tutur yang terdapat dalam dialog Ahok dengan masyarakat di Pulau Seribu. Tindak tutur yang dimaksud seperti tindak tutur lokusi, ilokusi, dan perlokusi. Metode yang digunakan dalam penelitian ini adalah metode deskriptif kualitatif, yaitu dengan mendeskripsikan data hasil penelitian. Hasil yang di dapat dalam penelitian ini tindak tutur lokusi dalam bentuk berita dengan fungsi menginformasikan sebanyak 61 tuturan sedangkan lokusi bentuk perintah dengan fungsi memerintah ditemukan paling sedikit dengan 5 tuturan. Tindak tutur ilokusi asertif dengan fungsi menyatakan sebanyak 64 tuturan sedangkan ilokusi deklaratif dengan fungsi membatalkan 1 tuturan. Tindak tutur perlokusi dengan fungsi membuat senang sebanyak 10 tuturan sedangkan perlokusi dengan fungsi membuat maklum dan membuat kesal sebanyak 2 tuturan.
\end{abstract}

Kata Kunci: tindak tutur, dialog ahok, tindak tutur lokusi, ilokusi, dan perlokusi

\section{PENDAHULUAN}

Bahasa pada dasarnya alat berinteraksi atau alat berkomunikasi, dalam arti alat untuk menyampaikan pikiran, gagasan, konsep, atau juga perasaan. Hal tersebut menjelaskan bahwa dalam kehidupan bermasyarakat, manusia sebagai makhluk sosial memiliki hubungan dan interaksi yang erat dengan sesamanya. Interaksi manusia ditujukan untuk dapat berkomunikasi dengan orang lain dengan menggunakan berbagai cara baik secara lisan maupun tulisan karena pada hakikatnya, komunikasi merupakan aktivitas yang tidak dapat dipisahkan dari kegiatan sehari-hari.

Bahasa yang digunakan dalam komunikasi bermasyarakat adalah tuturan. Manusia menggunakan tuturan untuk menjelaskan segala sesuatu yang ingin diungkapkannya terhadap lawan tuturnya. Hal tersebut berlaku sebaliknya pada lawan tutur yaitu dengan memberikan umpan balik terhadap penuturnya. Penggunaan tuturan dalam interaksi bermasyarakat membuat manusia memiliki ciri khas yang berbeda dengan makhluk lainnya. Ciri khas yang 
berbeda-beda tersebut menjadikan banyak tercipta ragam jenis tuturan. Ragam jenis tuturan tersebut ada yang memiliki makna langsung ketika diucapkan dan ada pula yang perlu ditelusuri terlebih dahulu ketika ingin mengetahui maknanya. Penutur dan lawan tutur dapat memanfaatkan konteks untuk memudahkan memahami makna tuturan.

Interaksi yang berlangsung dalam tindak tutur melibatkan dua unsur pokok yaitu penutur dan mitra tutur. Penutur adalah seseorang yang melakukan tindak verbal, sedangkan mitra tutur adalah seseorang yang menjadi lawan dari penutur. Komunikasi dan kegiatan berbahasa lainnya yang melibatkan penutur dan mitra tutur tersebut menghasilkan aspek yang disebut dengan tuturan.

Tuturan yang terjadi dalam sebuah interaksi berbahasa memiliki bermacammacam maksud yang ingin disampaikan. Berkenaan dengan bermacam-macam maksud tersebut, Leech (1993:19-20) menyatakan bahwa sebuah tindak tutur mencakup (1) penutur dan mitra tutur (2) konteks tuturan (3) tujuan tuturan (4) tindak tutur sebagai bentuk tindak atau aktivitas (5) tuturan sebagai produk tindak verbal.

Konteks tuturan dalam bermasyarakat dapat berupa lisan atau tulisan. Pada komunikasi lisan, pihak yang melakukan tindak tutur adalah penutur (pembicara) dan pihak yang menerima tindak tutur adalah mitra tutur (penyimak), sedangkan dalam komunikasi tulis, tuturan disampaikan oleh penulis (penutur) kepada mitra tutur yaitu pembaca. Penggunaan bahasa lisan dalam dialog merupakan salah satu bentuk komunikasi yang berlangsung dalam interaksi umum. Komunikasi yang terjalin diantara pembicara dan pendengar diharapkan dapat menyalurkan ide atau gagasan masing-masing sehingga dapat dipahami, diterima, dan diikuti oleh orang lain sebagai lawan tutur.

Tindak tutur yang dilakukan dalam dialog memiliki maksuddan tujuan dari setiap penutur terhadap mitra tutur. Tujuan dan maksud tersebut tidak secara langsung diungkapkan secara jelas terhadap mitra tuturkhususnya dalam kegiatan diskusi. Tujuan dan maksud tersebut diungkapkan melalui implikasi-implikasi yang mengharuskan mitra tutur untuk memahaminya. Berdasarkan hal tersebut, penulis ingin mengetahui tindak tutur beserta maksud tuturan dalamdialog Ahok dengan masyarakat di Pulau Seribu.

\section{METODE PENELITIAN}

Penelitian ini menggunakan metode deskriptif kualitatif. Metode deskriptif kualitatif yang digunakan adalah untuk menemukan pengetahuan yang seluas-luasnya terhadap jenis dan fungsi tindak tutur dalam. Penelitian ini memiliki tujuan untuk mendeskripsikan jenis dan fungsi tindak tutur dalam dialog Ahok dengan masyarakat di Pulau Seribu. 


\section{LANDASAN TEORI}

\section{Pragmatik}

Pragmatik adalah ilmu bahasa yang mengkaji tentang makna secara eksternal, yakni bagaimana satuan kebahasaan itu digunakan di dalam komunikasi. Pragmatik adalah cabang ilmu bahasa yang mempelajari struktur bahasa secara eksternal, yakni bagaimana satuan kebahasaan digunakan dalam komunikasi (Wijana, 1996:1-2). Senada dengan hal tersebut, menurut Kridalaksana (2001:176) pragmatik merupakan ilmu bahasa yang mempelajari isyarat-isyarat bahasa yang mengakibatkan keserasian pemakaian bahasa dalam komunikasi. Pragmatik mempelajari bagaimana bahasa digunakan dalam komunikasi, dan bagaimana pragmatik menyelidiki makna sebagai konteks, bukan sesuatu yang abstrak dalam komunikasi. Pendapat lain dikemukakan oleh Gazdar (dalam Nadar, 2009:5) bahwa Pragmatik adalah kajian antara lain mengenai deiksis, implikatur, presuposisi, tindak tutur dan aspek-aspek struktur wacana.

Menurut Parker (dalam Nadar, 2009:4) pragmatik adalah kajian tentangbagaimana bahasa digunakan untuk berkomunikasi, dan menegaskan bahwa pragmatik tidak menelaah struktur bahasa secara internal seperti tata bahasa, melainkan secara eksternal. Pragmatik adalah studi tentang makna yang disampaikan oleh penutur (atau penulis) dan ditafsirkan oleh pendengar (atau pembaca). Sebagai akibatnya studi ini lebih banyak berhubungan dengan analisis-analisis tentang apa yang dimaksudkan orang dengan tuturantuturannya daripada dengan makna terpisah dari kata atau frasa yang digunakan dalam tuturan itu sendiri.Dengan kata lain, pragmatik adalah studi tentang maksud penutur.

Berdasarkan beberapa penjelasan di atas, dapat disimpulkan bahwapragmatik adalah cabang ilmu bahasa yang terkait dengan aspek pemakaian dalam suatu komunikasi.

\section{Tindak Tutur}

\section{a. Pengertian Tindak Tutur}

Tindak tutur merupakan gejala individual, bersifat psikologis dan keberlangsungannya ditentukan oleh kemampuan bahasa si penutur dalam menghadapi situasi tertentu. Dalam tindak tutur lebih dilihat pada makna atau arti tindakan dalam tuturannya (Chaer dan Agustina, 2004:50). Menurut Cunningsworth (melalui Tarigan, 1990: 41) teori tindak tutur merupakan teori yang memusatkan perhatian pada cara penggunaan bahasa dalam mengkomunikasikan maksud dan tujuan sangpembicara dan juga dengan maksud penggunaan bahasa yang dilaksanakannya. Tindak ujar (speech act) adalah fungsi bahasa sebagai sarana penindak. Semua kalimat atau ujaran yang diucapkan oleh penutur 
sebenarnya mengandung fungsi komunikasi tertentu. Tuturan dari seseorang (penutur) tentu saja tidak semata-mata hanya asal bicara, tetapi mengandung maksud tertentu (Mulyana, 2005: 80). Dari beberapa pendapat sebelumnya dapat disimpulkan bahwa tindak tutur adalah tuturan dari seorang penutur pada situasi tertentu di dalam interaksi sosial.

\section{b. Jenis Tindak Tutur}

Austin (dalam Chaer, 2004: 53) merumuskan adanya tiga jenis tindakan yang berlangsung sekaligus, yaitu tindak lokusi (locution art), tindak ilokusi (ilocutionary art), dan tindak perlokusi (perlocutionary $a c t)$.

\section{1) Lokusi}

Wijana (1996 : 17) Tindak tutur lokusi adalah tindak tutur untuk menyatakan sesuatu. Tindak tutur ini disebut sebagai The Act of SayingSomething. Tindak tutur lokusi adalah tindak tutur yang menyatakan sesuatu dalam arti "berkata" atau tindak tutur dalam bentuk kalimat yang bermakna dan dapat dipahami (Chaer dan Agustina, 2004: 53). Tindak tutur lokusi (locution act) berarti makna dasar atau referensi kalimat. Komunikasi lokusi bersifat ideasional. Tuturan lokusi adalah tuturan yang digunakan untuk menyatakan sesuatu (Mulyana, 2005 : 81).

Berdasarkan kategori gramatikal, bentuk lokusi dibedakan menjadi 3 yaitu:

1. Bentuk pernyataan (deklaratif)
Bentuk pernyataan berfungsi hanya untuk memberitahukan sesuatu kepada orang lain sehingga diharapkan pendengar untuk menarik perhatian.

2. Bentuk pertanyaan (interogatif)

Bentuk pertanyaan berfungsi untuk menanyakan sesuatu sehingga pendengar diharapkan memberikan jawaban atas pertanyaan yang diajukan.

3. Bentuk perintah (imperatif)

Bentuk perintah memiliki maksut agar pendengar memberi tanggapan berupa tindakan atau perbuatan yang diminta.

Beberapa penjelasan di atas, dapat ditarik kesimpulan tindak tutur lokusi adalah tindak tutur untuk menyatakan sesuatu yang pemakainnya tidak tergantung pada konteks.

\section{b. Ilokusi}

Ilokusi adalah tindak tutur yang biasanya diidentifikasikan dengankalimat performatif yang eksplisit. Tindak tutur ilokusi ini biasanya berkenaan dengan pemberian izin, mengucapkan terima kasih, menyuruh, menawarkan, dan menjanjikan (Chaer, 2004: 53). Berkaitan dengan hal tersebut, Wijana (1996: 18) mengungkapkan tindak tutur ilokusi adalah tindak tutur yang digunakan untuk melakukan sesuatu.

Tindak tutur ilokusi adalah apa yang ingin dicapai oleh penuturnya pada waktu menuturkan sesuatu dan dapat merupakan tindakan menyatakan, berjanji, minta maaf, 
mengancam, meramalkan, memerintah, meminta, dan lain sebagainya. Tindak ilokusi dapat dikatakan sebagai tindak terpenting dalam kajian dan pemahaman tindak tutur (Nadar, 2009: 14).

Searle (melalui Tarigan, 1968: 47-48) mengelompokkan tindak ilokusi yang menunjukkan fungsi komunikatif menjadi lima kategori. Lima kategori tindak ilokusi yang menunjukkan fungsi komunikatif antara lain sebagai berikut.

\section{Asertif}

Tindak ilokusi asertif ini melibatkan pembicara pada kebenaran proposisi yang diekpresikan. Adapun beberapa fungsi tuturan asertif yang terkandung dalam tuturan penutur terhadap mitra tuturnya dapat berfungsi untuk menyatakan, memberitahukan, menyarankan, membanggakan, mengeluh, menuntut, dan melaporkan.

\section{Direktif}

Tindak ilokusi direktif ini dimaksudkan untuk menimbulkan beberapa efek melalui tindakan sang penyimak. Adapun beberapa fungsi tuturan direktif yang terkandung dalam tuturan penutur terhadap mitra tuturnya dapat berfungsi untuk memesan, memerintahkan, memohon, meminta, menyarankan, menganjurkan, dan menasehati.

\section{Komisif}

Tindak ilokusi komisif ini melibatkan pembicara pada beberapa tindakan yang akan datang. Adapun beberapa fungsi tuturan komisifyang terkandung dalam tuturan penutur terhadap mitra tuturnya dapat berfungsi untuk menjanjikan, bersumpah, menawarkan,dan memanjatkan (doa).

\section{Ekpresif}

Tindak ilokusi ekpresif ini mempunyai fungsi untuk mengekpresikan, mengungkapkan, atau memberitahukan sikap psikologis sang pembicara menuju suatu pernyataan keadaan yang diperkirakan oleh ilokusi. Adapun beberapa fungsi tuturan ekpresif yang terkandung didalam tuturan penutur terhadap mitra tutur dapatberfungsi untuk mengucapkan terima kasih, mengucapkan selamat, memaafkan, mengampuni, menyalahkan, memuji, menyatakan belasungkawa, dan sebagainya.

\section{Deklaratif}

Tindak ilokusi deklaratif ini adalah ilokusi yang bila performasinya berhasil akan menyebabkan korespondensi yang baik antara proposisional dengan realitas. Adapun beberapa fungsi tuturan deklaratif yang terkandung dalam tuturan penutur terhadap mitra tutur dapat berfungsi untuk menyerahkan diri, memecat, membebaskan, membaptis, memberi 
nama, mengucilkan, menunjuk, menentukan, menjatuhkan hukuman, memvonis dan sebagainya.

Tindak ilokusi (illocutionary act) berarti tindak ujar yang isinya menyatakan sesuatu. Jenis komunikasinya bersifat interpersonal, sedangkan isinya mengandung tindakan (Mulyana, 2005: 81). Beberapa pendapat tersebut, dapat disimpulkan bahwa tindak tutur ilokusi adalah tindak tutur Ilokusi adalah suatu tindakan yang selain untuk menyatakan sesuatu juga untuk melakukan sesuatu dan tindak tutur ilokusi sangat bergantung pada konteks.

\section{c. Perlokusi}

Sebuah tuturan yang diutarakan seseorang seringkali mempunyai daya pengaruh (perlocutionary force), atau efek bagi yang mendengarnya. Efek atau daya pengaruh ini dapat secara sengaja atau tidak sengaja dikreasikan oleh penuturnya. Tindak tutur yang pengutaraannya dimaksudkan untuk mempengaruhi lawan tutur disebut dengan tindak tutur perlokusi (Wijana, 1996 : 21). Tindak tutur perlokusi adalah tindak tutur yang berkenaan dengan adanya ucapan orang lain sehubungan dengan sikap dan perilaku nonlinguistik dari orang lain. Misalnya, karena adanya ucapan dokter (kepada pasiennya) "Mungkin ibu menderita penyakit jantung koroner "maka si pasien akan panik lalu sedih. Ucapan si dokter itu adalah tindak tutur perlokusi
(Chaer, 2004: 4). Tindak tutur perlokusi adalah tindakan untuk mempengaruhi lawan tutur seperti memalukan, mengintimidasi, membujuk, dan lain-lain (Nadar, 2009: 15). Menurut Mulyana (2005: 81) tindak perlokusi(perlocution act) adalah hasil atau efek yang ditimbulkan oleh ujaran (terhadap pendengar). Tuturan perlokusi mengandung maksud tertentu yang diinginkan oleh penutur agar terlihat dalam suatu tindakan.Berdasarkan penjelasan di atas, tindak tutur perlokusi adalah efek atau daya pengaruh yang ditimbulkan dari apa yang diutarakan penutur kepada mitra tutur.

\section{Analisis Hasil dan Pembahasan}

\section{Analisis Hasil}

Data-data yang diperoleh dan dibahas merupakan tindak tutur yang terdapat dalam dialog Ahok dengan masyarakat di Pulau Seribu. Jenis tindak tutur yang ditemukan dalam dialog Ahok dengan masyarakat di Pulau Seribu meliputi tindak tutur lokusi, ilokusi dan perlokusi. Dilihat dari jenis lokusi terdapat bentuk berita, tanya dan perintah. Lokusi bentuk berita mendominasi dalam dialog Ahok dengan masyarakat di Pulau Seribu, selanjutnya bentuk tanya dan perintah. Dilihat dari tindak tutur ilokusi, ditemukan tindak ilokusi asertif, direktif, ekpresif, komisif dan deklaratif. Bentuk 
tindak tutur ilokusi asertif paling banyak muncul dalam penelitian ini, kemudian disusul ekspresif, direktif langsung, komisif, dan terakhir deklaratif. Dilihat dari tindak tutur perlokusi dalam penelitian ini, ditemukan bentuk tindak tutur perlokusi yang paling banyak muncul adalah membuat senang, selanjutnya membuat tertarik, mengurangi ketegangan, melakukan sesuatu, membuat terbujuk, membuat maklum, dan membuat kesal.

Berdasarkan penelitian yang dilakukan dalam dialog Ahok dengan masyarakat di Pulau Seribu, ditemukan fungsi tindak tutur menginformasikan, bertanya, memerintah, menyatakan, menyebutkan, menunjukkan, mengakui, menuntut, mempertahankan, menyanggah, meminta, menyarankan, mengeluh, menyindir, mengucapkan maaf, mengucapkan terima kasih, mengucapkan salam, mengkritik, memuji, mengizinkan, melarang, menawarkan, membatalkan, melakukan sesuatu, mengurangi ketegangan, membuat senang, membuat terbujuk, membuat tertarik, membuat maklum, dan membuat kesal.

Untuk lebih jelasnya, jenis dan fungsi tindak tutur yang ditemukan dalam dialog Ahok dengan masyarakat di Pulau Seribu dapat dilihat pada tabel 1 . 


\begin{tabular}{|c|c|c|c|c|c|c|}
\hline No & $\begin{array}{c}\text { Jenis } \\
\text { Tindak } \\
\text { Tutur }\end{array}$ & Bentuk & \multicolumn{2}{|r|}{ Fungsi } & $\begin{array}{l}\text { Sub } \\
\text { total }\end{array}$ & Total \\
\hline \multirow{3}{*}{1} & \multirow{3}{*}{ Lokusi } & Berita & & Menginformasikan & 61 & \multirow{3}{*}{79} \\
\hline & & Tanya & & Bertanya & 13 & \\
\hline & & Perintah & & Memerintah & 5 & \\
\hline \multirow{21}{*}{2} & \multirow{21}{*}{ Ilokusi } & & \multirow{7}{*}{ Asertif } & Menyatakan & 64 & \multirow{7}{*}{99} \\
\hline & & & & Menyanggah & 4 & \\
\hline & & & & Menuntut & 2 & \\
\hline & & & & Mempertahankan & 3 & \\
\hline & & & & Mengakui & 4 & \\
\hline & & & & Menyebut & 18 & \\
\hline & & & & Menunjukkan & 4 & \\
\hline & & & \multirow{3}{*}{ Direktif } & Meminta & 23 & \multirow{3}{*}{55} \\
\hline & & & & Memerintah & 15 & \\
\hline & & & & Menyarankan & 17 & \\
\hline & & & \multirow{7}{*}{ Ekspresif } & Mengeluh & 5 & \multirow{7}{*}{65} \\
\hline & & & & Memuji & 8 & \\
\hline & & & & Mengkritik & 10 & \\
\hline & & & & Meminta Maaf & 1 & \\
\hline & & & & Menyindir & 18 & \\
\hline & & & & Berterimakasih & 11 & \\
\hline & & & & Mengucapkan salam & 12 & \\
\hline & & & Komisif & Menawarkan & 20 & 20 \\
\hline & & & \multirow{3}{*}{ Direktif } & Mengizinkan & 2 & \multirow{3}{*}{12} \\
\hline & & & & Melarang & 9 & \\
\hline & & & & Membatalkan & $\mathbf{1}$ & \\
\hline \multirow{7}{*}{3} & \multirow{7}{*}{ Perlokusi } & & \multirow{7}{*}{$\begin{array}{c}\text { Memberikan } \\
\text { Pengaruh }\end{array}$} & Melakukan Sesuatu & 5 & \multirow{7}{*}{35} \\
\hline & & & & $\begin{array}{l}\text { Mengurangi } \\
\text { Ketegangan }\end{array}$ & 6 & \\
\hline & & & & Membuat Senang & 10 & \\
\hline & & & & Membuat Terbujuk & 3 & \\
\hline & & & & Membuat Tertarik & 7 & \\
\hline & & & & Membuat Maklum & 2 & \\
\hline & & & & Membuat Kesal & 2 & \\
\hline
\end{tabular}

Tabel. 1 Tindak Tutur dalam dialog Ahok

Berdasarkan tabel 1 di atas, tindak tutur lokusi yang paling banyak ditemukan dalam penelitian ini adalah bentuk berita dengan fungsi menginformasikan sebanyak 61tuturan sedangkan lokusi bentuk perintah dengan fungsi memerintah ditemukan paling sedikit dengan 5 tuturan. Hal ini terjadi karena sebagaian besar tuturan yang dilakukan oleh pihak penutur terhadap warga (lawan tutur) dalam dialog Ahok dengan masyarakat di Pulau Seribu berisi tuturan memaparkan topik dialog kepada lawan tutur tanpa mempengaruhi lawan tutur 
untuk menaruh perhatian. Selanjutnya, tindak tutur ilokusi yang paling banyak muncul adalah ilokusi asertif dengan fungsi menyatakan sebanyak 64 tuturan sedangkan ilokusi deklaratif dengan fungsi membatalkan muncul lebih sedikit dengan 1 tuturan. Hal tersebut dikarenakan dalam kegiatan diskusi baik pihak penutur ataupun mitra tutur lebih banyak mengungkapkan pendapat pribadi maupun kelompok dengan tuturan berisi pernyataan agar mitra tutur tertarik untuk memberikan penjelasan. Berikutnya, selain tindak tutur lokusi dan ilokusi, ditemukan tindak tutur perlokusi dengan fungsi membuat senang yang lebih banyak muncul sebanyak 10 tuturan sedangkan perlokusi dengan fungsi membuat maklum dan membuat kesal lebih sedikit muncul masing-masing sebanyak 2 tuturan. Perlokusi ini muncul dikarenakan penutur memberikan informasi-informasi yang berpihak pada masyarakat pulau Seribu yang menginginkan pertumbuhan ekonomi di Pulau Seribu meningkat. Sehingga penutur lebih sering mengungkapkapkan hal-hal yang membuat masyarakat senang akan perubahan.

\section{Pembahasan}

Berdasarkan penelitian tindak tutur dialog Ahok dengan masyarakat di Pulau Seribu ditemukan tindak tutur lokusi, ilokusi dan perlokusi. Berikut jenis tindak tutur dengan masing-masing fungsi dalam dialog Ahok dengan masyarakat di Pulau Seribu.

\section{a. Tindak Tutur Lokusi}

Tindak tutur lokusi adalah tindak mengucapkan sesuatu yang tidak terkait dengan konteks. Jika melihat hasil penelitian dalam dialog Ahok dengan masyarakat di Pulau Seribu ditemukan adanya lokusi bentuk berita, bentuk tanya dan bentuk perintah.

\section{1) Bentuk Berita}

Dalam Tata Bahasa Indonesia, bentuk berita pada umumnya digunakan oleh penutur untuk membuat pernyataan sehingga isinya merupakan informasi bagi mitra tuturnya. Bentuk berita sama dengan bentuk pernyataan yakni berfungsi hanya untuk memberitahukan informasi terhadap orang lain (lawan tutur) . Bentuk berita (pernyataan) biasanya diakhiri dengan tanda titik pada akhir tuturan. Lokusi bentuk berita dalam penelitian ini dapat dilihat sebagai berikut.

(1) Ahok : Yang

sayahormatianggota

DPR RI dari Dapil DKI, juga DPRD DKI, ada Pak Bupati, tentu 


juga bapak Dinas
Kepala Biro, dan juga
ada bapak-bapak dari
Kelautan Perikanan,
untuk semua tokoh
masyarakat yang hadir
juga di tempat ini.

(2) Bapak Penanya 2 : Nama saya Sahrul, Pak, kebetulan saya ketua

$\mathrm{KNC}$ perwakilan masyarakat

Pulau

Seribu dan mohon izin

Pak Ketua, Pak

Payakun, saya juga wakil ketua Golkar Pulau Seribu, Pak.

(3) Ahok : Inilah pancasila kita. Kita bukan Negara kapitalis. Kita Negara pancasilais.

Data tuturan (1) merupakan pernyataan penutur yakni Ahok terhadap para tamu dan masyarakat Pulau Seribu. Tuturan yang dituturkan oleh Ahok di atas hanya memiliki maksud untuk memberikan sebuah informasi tentang siapa saja yang hadir kepada para tamu dan masyarakat Pulau Seribu. Tuturan pada data (2) dimaksudkan penutur (Bapak Penanya 2) untuk menginformasikan kepada pak Ahok tentang identitas dirinya. Tuturan data (2) yang dituturkan penutur (Ahok) tidak mengandung maksud untuk mempengaruhi lawan tutur (masyarakat Pulau Seribu). Selanjutnya, data tuturan penutur

(Ahok) menginformasikan terhadap lawan tutur bahwa negara Indonesia adlah negara pancasila. Tuturan di atas merupakan lokusi berita yang bertujuan untuk menyampaikan suatu informasi terhadap lawan tutur.

Dari beberapa contoh di atas, lokusi bentuk berita hanya berfungsi untuk menginformasikan sesuatu terhadap lawan tutur saja. Penutur menyatakan sesuatu dengan apa adanya tanpa ada maksud lain yang diinginkan penutur terhadap lawan tutur dalam diskusi tersebut.

\section{2) Bentuk Tanya}

Bentuk tanya (pertanyaan) secara formal ditandai oleh kehadiran kata tanya seperti apa, siapa, berapa, 
kapan, dan bagaimana dengan atau tanpa partikel -kah sebagai penegas. Bentuk tanya biasanya diakhiri dengan tanda tanya (?) di akhir tuturan. Bentuk tanya terdiri dari dua macam yakni tanya yang hanya memerlukan jawaban ya atau tidak dan tanya yang memerlukan penjelasan dari orang yang ditanya. Lokusi bentuk tanya dalam dialog Ahok dengan masyarakat Pulau Seribu dapat dilihat pada data berikut.

(4) Ahok : Dia makan itu pisang sama ikan, selama kerja disana. Kenapa?

(5) Protokol : Oh, masih Pak?

(6) Ahok: Pak Mansyur merasa saingan gak dengan bos baru?

Pada tuturan data (4) di atas menunjukkan lokusi bentuk tanya yang diungkapkan Ahok kepada pendegar terkait seorang teman yang diceritakannya hanya makan pisang. Tuturan data (4) dimaksudkan penutur untuk menanyakan terhadap lawan tutur yakni masyarakat, mengapa temannya di Pulau Belitung hanya makan pisang. Penutur tidak memiliki maksud lain selain bertanya terhadap lawan tuturnya berada dalam dialog tersebut. Selanjutnya, tuturan data

protokol benar-benar bertanya kepada pak Ahok, apakah masih boleh masyarakat memberikan pertanyaan kepadanya. Dan pada tuturan (6) terdapat lokusi bentuk tanya yang diungkapakan penutur terhadap pak Mansyur. Penutur menanyakan apakah pak Mansyur merasa saingan dengan rekan kerjanya yang lain. Oleh sebab itu, pertanyaan yang dituturkan Ahok dan moderator kepada pendengar merupakan lokusi bentuk tanya dengan fungsi bertanya. Berdasarkan beberapa contoh di atas, dapat disimpulkan bahwa lokusi bentuk tanya berfungsi untuk bertanya terhadap lawan tutur agar memberikan jawaban yang dibutuhkan oleh penutur tanpa tendensi apa-apa. Lokusi bentuk tanya sering muncul dalam sebuah diskusi dikarenakan pihak peserta biasanya ingin mengetahui lebih jelas alasan dari tanggapan yang dipaparkan pada diskusi tersebut.

\section{3) Bentuk Perintah}

Bentuk perintah terbagi menjadi bentuk perintah sebenarnya, permohonan, larangan, ajakan, dan persilahan. Bentuk perintah memiliki fungsi agar lawan tutur 
segera melakukan perbuatan yang diperintahkan oleh penutur. Berikut dapat dilihat data tindak tutur lokusi bentuk perintah dalam dialog Ahok dengan masyarakat di Pulau Seribu.

(7) Ahok : Saya kira itu silakan kalau mau tanya.

(8) Protokol : Silakan Bapak-Ibu atau rekan-rekan ada yang ingin ditanya? Satu termin saja.

(9) Ahok : Jadi saya sudah tugaskan pasar Jaya. Dan food station sama Dharma Jaya.

Tuturan silakan kalau mau tanya pada data (7) dan Silakan BapakIbu atau rekan-rekan ada yang ingin ditanya (8)merupakan tuturan lokusi bentuk perintah persilahan. Penutur dan moderator memerintahmitra tutur yakni penanya untuk segera bertanyaterhadap pihak penutur (Ahok). Berikutnya tuturan (9) merupakan perintah dalam bentuk penugasan kepada bawahan pak Ahok untuk segera membangun pasar Jaya kepada pihak Dharma Jaya.Lokusi tersebut termasuk dalam lokusibentuk perintah yang bertujuan agar lawan tutur (pihak peserta)melakukan tindakan yang sesuai dengan isi perintah tersebut.Berdasarkan analisis data tuturan (7), (8) dan (9) maka dapatdisimpulkan bahwa lokusi bentuk perintah hanya berfungsi untukmenyuruh agar lawan tutur segera melakukan tindakan yang diperintahkanoleh penutur tanpa memberikan suatu pengaruh.

\section{b. Tindak Tutur Ilokusi}

Tindak tutur ilokusi adalah tindak tutur yang selain untuk menyatakan sesuatu juga untuk melakukan sesuatu dan tindak tutur ilokusi sangat bergantung pada konteks. Berdasarkan penelitian Tindak Tutur dalam dialog Ahok dengan masyarakat di Pulau Seribu ditemukan tindak ilokusi asertif, direktif, ekpresif, komisif dan deklaratif. Berikut contoh ilokusi asertif, direktif, ekpresif, komisif dan deklaratif.

\section{1) Asertif}

Tindak tutur asertif adalah tuturan yang mengikat penuturnya akan kebenaran atas apa yang diujarkannya. Tuturan jenis ilokusi asertif mendominasi dari keseluruhan jenis ilokusi. Berikut contoh data ilokusi asertif yang ditemukan dalam penelitian ini.

(10) Ahok : Tapi putus sekolah di Jogja, yang SMA itu rata-rata ada mencapai 
14\%. 13 deh 13\%. Di

Jakarta hanya 0,4 .

(11) Ahok : Pemda? Enak aja duit Pemda kok masak gratis, bagi dong, uda untung gua balikin.

(12) Ahok : Saya nggak mau lagi pemerintah subsidi 7 ribu per kilo.

(13) Ahok : Nah, jadi teori saya, saya sudah bilang ke bapak Darjamhuni, orang yang punya dua saya kasi dua, punya satu kasi satu, punya lima kasi lima, yang gak punya gak kasi.

(14) Ahok : Saya ingat kemarin di psikotest dikasih gambar, saya gambar laut.

(15) Ahok : Tapi kalau koperasi didirikan dari pembudidaya yang jujur dan rajin, dia pribadi dapet $80 \%$ udah kaya, lalu 20\% kalau di koperasi yang dia juga anggota di dalamnya.

(16) Ahok : Kita udah mencapai 78, 99, Jakarta tertinggi di seluruh Indonesia.
Tuturan pada data (10) memiliki dua maksud yang terkandung di dalamnya yakni menginformasikan tingkat putus sekolah sebagai makna lokusi dan menyatakan sebagai makna ilokusi. Tuturan ilokusi asertif dengan fungsi menyatakan tersebut yaitu penutur menyatakan bahwa tingkat putus sekolah di Jogja, khususnya SMA mencapai $13 \%$ sedangkan di Jakarta $0,4 \%$. Oleh karena itu, tuturan data (10) termasuk dalam ilokusi asertif dengan fungsi menyatakan dikarenakan di dalam tuturan tersebut berisi tuturan pernyataan yang mengandung kebenaran bahwa tingkat putus sekolah di Jogja mencapai 13\% sedangkan Jakarta $0,4 \%$. Data tuturan (11) menyatakan ketidaksepahaman penutur terhadap hal yang terjadi, di mana Pemda mendapatkan bagian atas hasil kerja masyarakat, sehingga penutur menyanggahnya dan memberikan pendapatnya terkait hal itu. Tuturan pada (11) yang dituturkan oleh penutur tersebut selain memiliki maksud untuk pendapatnya, juga bermaksud untuk menyanggah hal yang selama ini sering terjadi. Selanjutnya, data tuturan (12) selain memiliki maksud untuk 
menginformasikan sebagai makna lokusi juga memiliki maksud untuk menuntut sebagai makna ilokusi. Tuturan menuntut yang dimaksud adalah bahwa penutur merasa keberatan dengan pemerintah yang mensubsidi beras 7000 per kilo (sebagai informasi/lokusi) dan menuntut agar pemerintah tidak lagi melakukan hal itu (sebagai tuntutan/ilokusi). Tuturan data (13) yang disampaikan penutur, selain merupakan penyampaian informasi tentang pendapatnya mengenai orang yang berhasil dan tidak, tuturan tersebut juga bermaksud mempertahankan keyakinannya atau penggunaan teori berpikirnya, bahwa ketika seseorang berhasil, maka ia akan memberikan sebesar yang dihasilkannya, begitupun sebaliknya. Tuturan data (14) memiliki jenis tuturan lokusi dan ilokusi. Makna lokusi adalah ketika penutur menginformasikan bahwa ia menggambar laut ketika psikotest dan makna ilokusinya adalah ia mengakui bahwa ia menggambar laut sebagai keinginannya akan budidaya. Tuturan data (15) menginformasikan kepada pembudidaya akan pembagian hasil dari budidaya yang akan dilakukan (lokusi), sekaligus juga menyebutkan bahwa pembudidaya yang baik akan mendapatkan $80 \%$ dari hasil budidaya dan 20\% lagi ketika ia mmenjadi anggota koperasi (ilokusi). Terakhir, tuturan data (16) selain menginformasikan indeks pembangunan manusia di Jakarta (lokusi), juga menunjukkan bahwa indeks pembangunan di Jakarta sudah mencapai 78,99 dan tertinggi di seluruh Indonesia. Berdasarkan beberapa contoh data di atas, dapat ditarik kesimpulan bahwa ilokusi asertif adalah ilokusi yang hanya mengikat penuturnya pada kebenaran proposisi yang diungkapkan.

\section{2) Direktif}

Tindak tutur direktif adalah tuturan yang dimaksudkan untuk menimbulkan beberapa efek melalui tindakan sang penyimak. Tuturan direktif dalam penelitian ini dapat dilihat pada data berikut.

(17) Ibu Penanya 1 : Soal produk kerupuk minta diadakan pemasaran, sama minta diadakan peralatannya, Pak. 
$\begin{array}{ll}\text { (18) Protokol } & \text { Ini hanya } \\ & \text { satu termin } \\ & \text { lagi, dua } \\ & \text { orang saja, } \\ & \text { setelah itu } \\ & \text { kita lihat ke } \\ \text { lapangan. } & \text { Oke silahkan. }\end{array}$

(19) Ibu Penanya 5 : Kalau bapak bersedia sudi kirananya

melihat

tempat

kegiatan

kami, Pak, di hutan

Eduwisata.

Pada data tuturan (17) dalam hal ini penanya menginformasikan tentang pemasaran produk kerupuk dan pemasarannya (lokusi), selain itu juga meminta secara langsung kepada mitra tutur (Ahok) agar usaha kerupuk yang mereka lakoni mendapatkan pemasaran dan meminta peralatan yang dapat menunjang produksi kerupuk mereka (ilokusi). Pada data tuturan (18) selain protokol menginformasikan bahwa ada satu termin lagi untuk bertanya kepada pak Ahok (lokusi), juga menyampaikan tuturan dengan maksud memerintah penanya agar tidak ada lagi yang sertanya setelah ini karena mereka akan pergi ke lapangan (ilokusi). Pada data tuturan (19) selain penanya menginformasikan bahwa ada sebuah hutan Eduwisata yang dikelolanya (lokusi), penanya juga menyarankan agar pak Ahok datang ke hutan Edukasi tersebut (ilokusi). Berdasarkan analisis data tuturan di atas, dapat disimpulkan bahwa ilokusi direktif berisi tuturan yang mempengaruhi lawan tutur untuk melakukan sesuatu sesuai dengan apa yang dituturkan oleh penutur.

\section{3) Ekpresif}

Tuturan ilokusi ekpresif adalah tuturan untuk mengekpresikan, mengungkapkan, atau memberitahukan sikap psikologis sang pembicara menuju suatu pernyataan keadaan yang diperkirakan. Berdasarkan penelitian yang dilakukan, ditemukan tindak ilokusi ekpresif sebagai berikut.

(20) Ahok : Ya kalo di Papua kan repot saya Pak.

(21) Ahok : Pulau Seribu nggak ada tempat yang lebih hebat lagi, deket ibu kota, satu jam saja, setengah jam udah liat laut yang bagus. 
(22) Ahok : Namanya bantuan kapal, di pusat, udah korupsi kadangkadang, kayunya jelek, ruasnya jelek.

(Hal. 2)

(23) Ahok : Jadi saya mohon maaf, saya ngerti banyak orang yang gak suka sama saya karena cara saya berlawanan dengan yang ada puluhan tahun di benak bapak ibu. (Hal. 13)

(24) Ahok : Bukan koperasi unit desa. Kepala untung duluan.

(25) Bapak Penanya 7 : Saya

berterimak
asih
kepada
dinas,
camat,
sudah
membantu
kami pada
2014.

(26)Bapak Penanya 6:

Bismillahirrahmanirrahim,

Assalamualaikum

warahmatullahwbarakatuh.

Berdasarkan tuturan di atas, tuturan pada data (20) merupakan tuturan yang mengandung dua maksud yakni maksud menginformasikan sebagai makna lokusi dan mengeluh sebagai makna ilokusi. Sebagai makna ilokusi, penutur merasa tidak ingin pergi ke Papua sehingga tuturan tersebut bermakna mengeluh atau keluhan kalau penututr di tempatkan di Papua. Selanjutnya, tuturan pada data (21) selain bermaksud untuk menginformasikan sebagai makna lokusi juga mengandung maksud memuji sebagai makna ilokusi. Tuturan yang dimaksudkanj, selain memberikan informasi tentang keindahan Pulau Seribu, penutur juga memberikan makna pujian atau memuji Pulau Seribu di hadapan masyarakat Pulau Seribu sebagai wujud penghargaan kepada Pulau Seribu agar masyarakat Pulau Seribu lebih mengembangkan lagi potensi yang dimilki oleh Pulau Seribu tersebut. Data pada tuturan (22) selain bermaksud menginformasikan sebagai makna lokusi juga bermaksud mengkritik terhadap pihak pemerintah yang memberikan kapal dalam bentuk tidak layak. Dibalik kritikan terhadap kapal, penutur juga sekaligus mengkritik cara kerja pemerintah yang tidak baik dan 
dianggap korupsi. Tuturan pada data (23) merupakan tuturan ilokusi ekpresif dengan fungsi meminta maaf. Permintaan maaf itu terkait kesadaran diri penutur yangmerasa dirinya kurang baik sehingga ada sebagian orang yang tidak suka dan membencinya, oleh karena itu penutur meminta maaf dengan tujuan agar pendengar menerima dan memafkannya. Tuturan pada data (24) memiliki fungsi lokusi dan ilokusi. Sebagai fungsi lokusi, penutur menginformasikan kelemahan sistem kerja koperasi desa. Senagai fungsi sindiran/menyindir, tuturan ini bermaksud agar sistem koperasi dibangun diatas kebijakan, jadi bukan Kepala Untung Duluan, melainkan Koperasi Unit Desa. Jadi diharapkan setelah mendengar sindiran ini, pihak tertentu yang digolongkan dalam hal koperasi tidak lagi berlaku seenaknya, melainkan juga harus mementingkan warga. Tuturan pada data (25) mengandung dua maksud yakni menginformasikan sebagai makna lokusi dan mengucapkan terima kasih sebagai makna ilokusi. Tuturan dengan maksud mengucapkan terima kasih tersebut dituturkan penanya terhadap pihak kedinasan dan camat yang sudah membantu mereka dalam menjalankan usahanya. Berikutnya data tuturan (26) mengandung dua maksud yakni maksud menginformasikan sebagai makna lokusi dan mengucapkan salam sebagai makna ilokusi. Tuturan mengucapkan salam tersebut dituturkan oleh penanya atas rasa syukur dan senangnya atas keberhasilan yang dibantu oleh pihak kedinasan dan camat. Berdasarkan penjelasan di atas, tindak tutur ilokusi ekpresif merupakan tuturan yang berisi pernyataan penutur untuk menunjukkan sikap psikologis penutur terhadap suatu keadaan dalam dialog.

\section{4) Komisif}

Tindak tutur ilokusi komisif adalah tindak tutur yang melibatkan pembicara pada beberapa tindakan yang akan datang. Berikut contoh data ilokusi komisif.

(27) Ahok: Nggak usah beli ini tanah, nanti kalau semua tambak berhasil, kita akan bangun pasar.

Tuturan yang disampaikan pada data (27) selain berisi tuturan menginformasikan sebagai makna 
lokusi juga berisi tuturan menawarkan sebagai makna ilokusinya. Tuturan menawarkan yang dimaksud adalah memberikaan penawaran terhadap masyarakat untuk mengembangkan tambak dan apabila hasilnya bagus, maka pemerintah akan membangun pasar di Pulau Seribu untuk memperdagangkan hasil tambak mereka kepada khalayak umum.

\section{5) Deklaratif}

Tindak tutur ilokusi deklaratif adalah tuturan bila performasinya berhasil akan menyebabkan korespondensi yang baik antara proposisional dengan realitas. Ilokusi komisif dalam penelitian ini dapat dilihat pada data berikut.

(29) Ahok : Gakpapa tanya aja.

(30) Ahok : Yang penting kalau Bapak-Ibu sakit jangan maen dokter-dokteran, sinsei-sinsei-an ya, jangan beli cap naga, cap gajah, cap beruang, cap macan, sembarangan minum lho. Nanti kena stroke nanti.

(31) Protokol : Ibu lain kali lagi ya karena bapak masih harus lihat lagi lapangan.
Tuturan pada data (29) dituturkan penutur terhadap moderator dan penanya, selain memiliki maksud menginformasikan sebagai makna lokusi juga memiliki maksud mengizinkan sebagai makna ilokusi. Tuturan pengizinan penanya pada data (29) adalah mengizinkan penanya untuk mengajukan pertanyaan terhadap pihak penutur dalam dialog tersebut walaupun sebenarnya termin pertanyaan sudah habis. Tuturan pada data (30) selain memiliki maksud menginformasikan terhadap pendengar sebagai makna lokusi juga memiliki maksud melarang sebagai makna ilokusinya. Tuturan " Jangan main dokter-dokteran", yang disampaikan penutur dimaksudkan sebagai larangan agar warga tidak mengonsumsi obatobatan yang bukan diberikan resep langsung oleh dokter. Jadi, apabila sakit, maka lebih baik oeriksa ke dokter daripada penyakitnya tambah parah dan lagi dapat menimbulkan penyakit stroke. Berikutnya, tuturan pada data (31) terjadi selain mengandung maksud menginformasikan sebagai makna lokusi juga mengandung maksud membatalkan sebagai makna ilokusi. Tuturan ilokusi deklaratif dengan fungsi membatalkan yang dimaksud adalah menolak keinginan penanya 
untyk mengajukan pertanyaan karena penutur akan segera pergi ke lapangan.Berdasarkan analisis data di atas, dapat disimpulkan bahwa ilokusideklaratif adalah tuturan yang dimaksudkan penutur untuk menciptakanhal, status, keadaan yang baru dalam dialog apabila terjadi korespondensiyang baik antara proposisi dan realitas yang ada.

\section{c. Tindak Tutur Perlokusi}

Tindak tutur perlokusi adalah tuturan yang memiliki efek atau daya pengaruh yang ditimbulkan dari tuturan penutur terhadap mitra tutur. Berdasarkan penelitian yang dilakukan dalam dialog Ahok dengan masyarakat di Pulau Seribu ditemukan tindak perlokusi sebagai berikut.

(32) Ibu Penanya 5 : Mimpi kami pengen menjadi pasar sayuran khususnya di Kepulauan Seribu, Pak,

(33) Ahok : Mama saya percaya kalau makan udang itu anaknya pintar. Padahal orang bodoh dimarahi otak udang.

(34) Ahok : Kalau ini kita kerjakan setahun dua tahun dengan baik ya Pak ya, saya yakin Bapak-Ibu punya duit banyak pasti pada Haji-Hajjah gelarnya.

(35) Ahok : Jadi harga gula di Jakarta sama di Plau Seribu sama. Minyak goreng, tepung, nah saya mau usahakan sembakonya mirip.

(36) Ahok : Bapak-Ibu yang kerja $80 \%$, mana ada bos gitu baik hati, ya nggak? 80 Bapak Ibu loh. Kami 20.

(37) Ahok : Kalau gak enak, mutu gak baik, packaging gak baek kita akan keluarkan.

(38) Ahok : Jadi jangan percaya sama orang kan bisa aja dalam hati bapak ibu gak bisa pilih saya gitu kan, dibohongin pakai surat Al-Maidah 51.

Data tuturan (32) mengandung sebuah lokusi berupa informasi terhadap penutur. Ilokusi pada tuturan tersebut berupa tuturan yang memberikan pengaruh kepada Ahok selaku pemerintahan untuk melakukan sesuatu, yaitu mendirikan pasar sayuran bagi masyarakat Pulau Seribu. Tuturan data (33) berupa tuturan yang mengandung anekdot dengan tujuan 
mengurangi ketegangan dalam dialog tersebut. Mengurangi ketegangan berfungsi untuk membuat suasana lebih nyaman dan santai. Berikutnya, data tuturan (34) adalah yakni berupa lokusi dan perlokusi. Tuturan lokusi bermaksud memberi informasi kepada pendengar. Sedangkan tuturan yang mengandung perlokusi agar mitra tutur terpengaruh untuk terbujuk melalukan tambak budidaya yang dimaksudkan penutur. Penutur melakukan pembujukan dengan megatakan halhal baik (seperti akan naik haji) yang dapat diterima warga apabila tambak ini dijalankan dengan baik. Sehingga membuat warga terbujuk untuk melaksanakan tambak sesuai dengan yang diharapkan penutur. Tuturan data (35) mengandung lokusi informasi pada pendengar. Perlokusi pada data tutran (35) adalah berupa pengaruh yang membuat orang yang mendengar menjadi senang. Tuturan penutur yang disampaikan pada data (35) tetang sembako murah, akan membuat warga menjadi senang. Data tuturan (36) bermakna lokusi dan perlokusi. Lokusi pada data tuturan (36) adalah sebuah informasi terhadap pendengar. Tuturan yang disampaikan penutur memberikan pengaruh yang membuat pendengar menjadi tertarik akan apa yang disampaikan penutur. Tuturan tersebut mengandung hal-hal menarik demi keuntungan pendengar. Dalam data (36) ketertarikan itu muncul ketika penutur akan membagikan keuntungan dengan perbandingan 80\%-20\% untuk warga dan pemerintah. Selanjutnya data tuturan (37) Selain mengandung lokusi berupa informasi terhadap pendengar, tuturan ini juga mengandung makna perlokusi yang diharapkan dari tuturan tersebut adalah agar pendengar memaklumi apa yang disampaikan penutur. Pemakluman itu terjadi setelah pendengar menyadari bahwa, kalau memang kualitas produk yang dihasilkan masyarakat tidak baik, maka pemerintah tidak mau menerimanya, sehingga masyarakat memaklumi hal itu apabila suatu saat nanti produknya ditolak pemerintah. Tuturan pada data (38) muncul pada saat penutur mengucapkan tuturan yang menyakiti perasaan sebagian kalangan. Selain bermakna lokusi, yaitu menginformasikan sesuatu, tuturan ini juga memiliki makna perlokusi, yaitu membuat kesal pendengar. Pengaruh dari tuturan yang diucapkan penutur dalam data ini membuat pendengar tidak nyaman. Karena penutur menuturkan hal yang paling sensitif terkait tentang kepercayaan (agama) yang diyakini 
orang banyak. Sehingga membuat pendengar merasa kesal dan menimbulkan pengaruh yang tidak baik. Berdasarkan analisis data tuturan (32) s.d. (38) maka dapat disimpulkan bahwa tindak tutur perlokusi adalah tindak tutur yang memiliki daya pengaruh atau efek bagi mitra tutur yang mendengarkannya.

\section{SIMPULAN}

Berdasarkan pemaparan di atas, maka tindak tutur lokusi yang paling banyak ditemukan dalam penelitian ini adalah bentuk berita dengan fungsi menginformasikan sebanyak 61 tuturan sedangkan lokusi bentuk perintah dengan fungsi memerintah ditemukan paling sedikit dengan 5 tuturan. Hal ini terjadi karena sebagaian besar tuturan yang dilakukan oleh pihak penutur terhadap warga (lawan tutur) dalam dialog Ahok dengan masyarakat di Pulau Seribu berisi tuturan memaparkan topik dialog kepada lawan tutur tanpa mempengaruhi lawan tutur untuk menaruh perhatian.

Selanjutnya, tindak tutur ilokusi yang paling banyak muncul adalah ilokusi asertif dengan fungsi menyatakan sebanyak 64 tuturan sedangkan ilokusi deklaratif dengan fungsi membatalkan muncul lebih sedikit dengan 1 tuturan. Hal tersebut dikarenakan dalam kegiatan diskusi baik pihak penutur ataupun mitra tutur lebih banyak mengungkapkan pendapat pribadi maupun kelompok dengan tuturan berisi pernyataan agar mitra tutur tertarik untuk memberikan penjelasan.

Berikutnya, selain tindak tutur lokusi dan ilokusi, ditemukan tindak tutur perlokusi dengan fungsi membuat senang yang lebih banyak muncul sebanyak 10 tuturan sedangkan perlokusi dengan fungsi membuat maklum dan membuat kesal lebih sedikit muncul masing-masing sebanyak 2 tuturan. Perlokusi ini muncul dikarenakan penutur memberikan informasi-informasi yang berpihak pada masyarakat pulau Seribu yang menginginkan pertumbuhan ekonomi di Pulau Seribu meningkat. Sehingga penutur lebih sering mengungkapkapkan hal-hal yang membuat masyarakat senang akan perubahan.

\section{DAFTAR PUSTAKA}

Chaer, Abdul dan Leonie Agustina. 2004. Sosiolinguistik Perkenalan Awal. Jakarta: Rineka Cipta.

Kridalaksana, Hrimurti. 2001. Kamus Linguistik. Jakarta: Gramedia Pustaka Umum.

Mulyana. 2005. Kajian Wacana: Teori, Metode, dan Aplikasi Prinsip-prinsip Analisis Wacana. Yogyakarta: Tiara Kencana.

Nadar, F.X. 2009. Pragmatik dan Penelitian Pragmatik. Yogyakarta: Graha Ilmu.

Tarigan, Henry Guntur. 1990. Pengajaran Pragmatik. Bandung: Angkasa.

Wijana, I Dewa. 1996. Dasar-dasar Pragmatik. Yogyakarta: Andi 
